KS. TOMASZ ROZKRUT

Papieski Uniwersytet Jana Pawła II w Krakowie

\title{
SYNODY BISKUPÓW PAPIEŻA BENEDYKTA XVI
}

Treść: - 1. Troska kard. J. Ratzingera o funkcjonowanie Synodu Biskupów. - 2. Synody Biskupów Benedykta XVI. - 2.1. XI Zebranie Generalne Zwyczajne Synodu Biskupów (2005). - 2.2. XII Zebranie Generalne Zwyczajne Synodu Biskupów (2008). - 2.3. II Zebranie Specjalne Synodu Biskupów dla Afryki (2009). - 2.4. Synod Biskupów dla Bliskiego Wschodu (2010). - 2.5. XIII Zebranie Generalne Zwyczajne Synodu Biskupów (2012). - Podsumowanie.

Ważną instytucją Kościoła posoborowego, można powiedzieć, że nawet znakiem jego żywotności oraz dynamiczności, a przede wszystkim zatroskania o dobro wspólne, tak wewnątrz samego Kościoła jak również jako wyraz instytucjonalny jego aktywności względem współczesnego społeczeństwa, jest stosunkowo młoda oraz żywa instytucja Synodu Biskupów, która została powołana do istnienia w okresie Soboru Watykańskiego II przez papieża Pawła VI, w dużej mierze jako odpowiedź na przedsoborowe oraz soborowe propozycje w perspektywie rozpoczętego kościelnego aggiornamento ${ }^{1}$. Stąd też papież Paweł VI napisał we Wstępie do m.p. „Apostolica sollicitudo” z 15 września 1965 r. ustanawiającym instytucję Synodu Biskupów, że przede wszystkim obrady soborowe przekonały go o wadze oraz potrzebie korzystania ze współpracy biskupów w perspektywie dobra całego Kościoła. Dlatego też E. Sztafrowski powołując się na słowa Pawła VI stwierdza, że wynika z nich jasno, że powstanie Synodu Biskupów miało silny związek z soborową dyskusją na temat kolegialności².

${ }^{1}$ Zob. T. Rozkrut, Instytucja Synodu Biskupów w Kościele posoborowym, Tarnów 2010 .

2 E. Sztafrowski, Kolegialne działanie Biskupów na tle Vaticanum II. Studium dogmatyczno-kanoniczne, Warszawa 1975, s. 105n. 
Instytucja Synodu Biskupów nabrała szczególnej żywotności podczas długiego pontyfikatu papieża Jana Pawła II (1978-2005), który przewodniczył piętnastu jej zebraniom oraz zapowiedział Synod Biskupów na temat Eucharystii, który odbył się już za pontyfikatu papieża Benedykta $\mathrm{XVI}^{3}$. Także Jan Paweł II spowodował, że wydawane regularnie adhortacje apostolskie zostały dodatkowo określane jako posynodalne, co zapoczątkowało nową tradycję w dokumentach Biskupów Rzymskich a samemu dokumentowi nadało nieco inne znaczenie, gdyż owszem jest to dokument Biskupa Rzymskiego ale uwzględniający doradczy charakter instytucji Synodu Biskupów, który zawiera się, między innymi, w przedstawianych papieżowi przez Synod Biskupów propozycjach. Warto także przypomnieć, że wcześniej papież Paweł VI (1963-1978) zwołał pięć Synodów Biskupów ${ }^{4}$.

Nie dziwi więc, że także papież Benedykt XVI (2005-2013) regularnie zwoływał Synody Biskupów, kontynuując w ten sposób twórcze oddziaływanie Biskupa Rzymskiego na funkcjonowania współczesnego Kościoła powszechnego, który w tym zadaniu wspierany był głosem doradczym biskupów przybyłych do Rzymu, celem uczestniczenia w zebraniu tej centralnej instytucji współczesnego Kościoła.

Tytułem wprowadzenia należałoby także podkreślić, że Synod Biskupów pozostaje bardzo sprawną instytucją kanoniczną, o dużym potencjale teologicznym, w szczególności do podejmowania ważnych oraz aktualnych problemów współczesnego Kościoła, oraz pośrednio także żywotnych problemów społecznych, jak np. znaczenie oraz rola małżeństwa oraz rodziny we współczesnym świecie, która to problematyka była przedmiotem prac Synodu Biskupów w 1980 r., pozostając w ten sposób ważną inicjatywą Kościoła na współczesny kryzys wymienionych instytucji ${ }^{5}$.

3 Zob. T. Rozkrut, Synody Biskupów papieża Jana Pawła II, Tarnowskie Studia Teologiczne, 29, 2(2010), s. 23-36.

4 Zob. T. Rozkrut, Il Sinodo dei Vescovi nella Chiesa postconciliare. Brevi annotazioni sul contributo di Giovanni Paolo II, w: L. Gerosa (red.), Giovanni Paolo II: Legislatore della Chiesa. Fondamenti, innovazioni e aperture, Libreria Editrice Vaticana, Città del Vaticano 2013, s. 219-223.

5 Zob. T. Rozkrut, Instytucja Synodu Biskupów w Kościele posoborowym, dz. cyt., s. 219 n. 


\section{Troska kard. J. Ratzingera o funkcjonowanie Synodu Biskupów}

Zanim przejdziemy do prezentacji oraz analizy Synodów Biskupów zwołanych podczas zakończonego pontyfikatu, warto zwrócić uwagę na wystąpienie kard. Ratzingera, które miało miejsce w Rzymie podczas zebrania Rady Sekretariatu Generalnego Synodu Biskupów w kwietniu 1983 r. $^{6}$

Lektura opublikowanego tekstu pozwala na wyodrębnienie ważnych zagadnień, czy też wybranych interesujących myśli, które należałoby jednak uznać za bardziej teologiczne niż prawne, niemniej jednak są one godne przypomnienia oraz skomentowania, zwłaszcza w perspektywie zakończonego pontyfikatu.

I tak w swoim wystąpieniu na temat celów oraz metod Synodu Biskupów, J. Ratzinger, na samym początku postawił trzy interesujące pytania, do których pragnął się sukcesywnie w sposób merytoryczny odnieść ${ }^{7}$. Były one następujące:

1. Czym jest Synod Biskupów?

2. W jakim kierunku zmierza?

3. Jakie metody pracy sprzyjają wyznaczonemu celowi? ${ }^{8}$

Zwrócił także uwagę na to, że celem spotkania Rady Sekretariatu Generalnego Synodu Biskupów jest podjęcie refleksji nad naturą oraz funkcjonowaniem Synodu Biskupów, nie jest nim natomiast tylko opisanie rzeczywistości już istniejącej, ale jest nim właśnie podjęcie problematyki dotyczącej ulepszenia tejże instytucji, w szczególności

${ }^{6}$ Rada Sekretariatu Generalnego Synodu Biskupów, złożona z 15 biskupów i kardynałów pochodzących z różnych kontynentów, podczas spotkania w dniach 26-30 kwietnia 1983 r. za przedmiot swojej refleksji miała zagadnienie natury oraz funkcjonowania Synodu Biskupów. Na tym spotkaniu kard. J. Ratzinger przedstawił, z punktu widzenia teologicznego, problematykę dotyczącą celów oraz metod synodalnych. J. Tomko, Presentazione, w: J. Tomko (red.), Sinodo dei Vescovi. Natura, metodo, prospettive, Libreria Editrice Vaticana, Città del Vaticano 1985, s. 7-8.

7 J. Ratzinger, Scopi e metodi del Sinodo dei Vescovi, w: J. Tomko (red.), Sinodo dei Vescovi. Natura, metodo, prospettive, Libreria Editrice Vaticana, Città del Vaticano 1985, s. 45-58.

8 Tamże, s. 45. 
także zbadanie czy metody dotychczas stosowane są rzeczywiście odpowiednie dla wyznaczonych celów Synodu Biskupów9 ${ }^{9}$ W szczególności Kardynał zwrócił uwagę, czy aktualna figura prawna instytucji odpowiada jej celowi, którym jest ukazanie związku między misją Następcy św. Piotra a wspólną odpowiedzialnością całego Kolegium Biskupów, któremu - w jedności z Piotrem - została powierzona troska o Kościół powszechny ${ }^{10}$. Nie ulega zatem żadnej wątpliwości, że swoją refleksją J. Ratzinger chciałby usprawnić funkcjonowanie Synodu Biskupów oraz lepiej jeszcze ukazać naturę tejże instytucji, która, tak wówczas jak i teraz, pozostaje w ciągłym rozwoju. Łatwo także dopatrzyć się w jego myśli obecność doktryny eklezjologicznej Soboru Watykańskiego II, w szczególności tej dotyczącej episkopatu a zawartej w konstytucji dogmatycznej „Lumen gentium”; mówiąc jeszcze inaczej, jest to praktyczne jej urzeczywistnianie.

Warto również zwrócić uwagę na kontekst analizowanego wystąpienia. Miało ono miejsce trzy miesiące po promulgacji nowego Kodeksu Prawa Kanonicznego, który zawierał także normy na temat Synodu Biskupów, przy czym formalnie on jednak jeszcze nie obowiązywał ${ }^{11}$. Ponadto Kościół posiadał już doświadczenie pierwszych zebrań Synodów Biskupów, których do tego momentu, łącznie z tzw. Synodem Holenderskim, odbyto już siedem, a w których to zebraniach uczestniczył już kard. Ratzinger ${ }^{12}$.

Sukcesywnie J. Ratzinger zwrócił uwagę na sposób umiejscowienia Synodu Biskupów w nowym Kodeksie Prawa Kanonicznego i podkreślił, że taka kolokacja rodzi problem przede wszystkim w przedmiocie relacji Synodu Biskupów, nie tyle względem Biskupa Rzymskiego, co raczej względem samego Kolegium Biskupów. Wskazał, że celem rozwiązania zarysowanej problematyki konieczna jest analiza oraz porównanie definicji teologicznej instytucji Synodu Biskupów zawartej w kan. 342 oraz jej struktury prawnej opisanej przez sukcesywne ka-

9 Tamże.

${ }^{10}$ Tamże.

${ }^{11}$ KPK, kan. 342-348.

${ }^{12}$ Zob. T. Rozkrut, Instytucja Synodu Biskupów w Kościele posoborowym, dz. cyt., s. $212-220$. 
nony. Nie ulega wątpliwości, że kan. 342 wskazuje na trzy cele Synodu Biskupów i w ten sposób definiując instytucję określa także istotę Synodu Biskupów ${ }^{13}$.

Warto w tym miejscu przypomnieć, że kanony o tej centralnej instytucji Kościoła, mającej w chwili promulgacji nowego Kodeksu prawie osiemnaście lat, zostały umieszczone po kanonach o Biskupie Rzymskim i Kolegium Biskupów (kan. 330-341414) a przed kanonami na temat Kolegium Kardynałów (kan. 349-359) - taka była bowiem wyraźna wola ówczesnego kościelnego ustawodawcy papieża Jana Pawła II ${ }^{15}$, która bazowała z kolei na racji eklezjologicznej, której celem było, przede wszystkim, podkreślenie ścisłego związku Synodu Biskupów z zasadą kolegialności biskupów ${ }^{16}$. Ponadto dzięki takiej strukturze kodeksowej, Synod Biskupów został włączony do grupy instytucji odpowiedzialnych za zarządzanie Kościołem powszechnym ${ }^{17}$.

${ }^{13}$ J. RATZINGER, dz. cyt., s. 46n.

${ }^{14} \mathrm{~W}$ tej grupie kanonów, kan. 334, wymienia wprost Synod Biskupów jako instytucję świadczącą pomoc Biskupowi Rzymskiemu: „W wykonywaniu zadania, Biskupowi Rzymskiemu świadczą pomoc biskupi, którzy mogą to czynić w różny sposób, w tym także poprzez Synod Biskupów. Ponadto świadczą mu pomoc kardynałowie, a także inne osoby oraz różne instytucje stosownie do aktualnych potrzeb. Wszystkie te osoby i instytucje, w imieniu i jego władzą wykonują powierzone sobie zadanie dla dobra wszystkich Kościołów, zgodnie z normami określonymi w prawie”.

${ }^{15}$ „Invertatur ordo capitulorum, ita ut hoc Caput II («De Synodo Episcoporum») veniat post Caput III («De Sanctae Romanae Ecclesiae Cardinalibus»), propter praestantiam munerum quae Collegio Cardinalium committuntur, praesertim ipsa electio Romani Pontificis (tres Patres). R. Animadversio non recipitur. Summus Pontifex de hac quaestione interpellatus est a Praeside Commissionis, in Audientia die 28-3-1981 habita, suumque responsum fuit ordinem systematicum servandum esse uti iacet". Communicationes, 14, n. 1(1981), s. 180.

${ }^{16}$ E. GóRecki, Synod Biskupów, w: J. Krukowski (red.), Komentarz do Kodeksu Prawa Kanonicznego, Pallottinum 2005, t. 2/1, s. 174.

${ }^{17}$ J. I. Arrieta, Il Sinodo dei Vescovi. Rilevanza della prassi di attuazione in ordine al compimento delle sue finalità istituzionali, w: Pontificium Consilium de Legum Textibus Interpretandis, Ius in vita et in Missione Ecclesiae. Acta Symposii Internationalibus Iuris Canonici occurrente $\mathrm{X}$ anniversario promulgationis Codicis Iuris Canonici diebus 19-24 Aprilis 1993 in Civitate Vaticana Celebranti, Libreria Editrice Vaticana, Città del Vaticano 1994, s. 314. 
Kard. Ratzinger, stwierdził w analizowanym wystąpieniu, że po pierwsze: w przywołanym kanonie czytamy, że na Synodzie Biskupów zbierają się wybrani biskupi z różnych stron świata w celu pobudzania ścisłej łączności między Biskupem Rzymskim oraz nimi samymi ${ }^{18}$.

Po drugie: Synod Biskupów, swoją radą, świadczy pomoc Biskupowi Rzymskiemu, w tym co dotyczy zachowania oraz wzrostu wiary oraz obyczajów, jak również zachowania oraz umocnienia dyscypliny kościelnej ${ }^{19}$. Konkretnie - z punktu widzenia prawnego - zadaniem Synodu Biskupów jest doradzanie Biskupowi Rzymskiemu, w jasno określonej przestrzeni, która dotyczy wiary i obyczajów oraz dyscypliny kościelnej; mówiąc inaczej, celem prac synodalnych jest zadanie zachowania depozytu Kościoła, to znaczy obrona wiary oraz zachowanie, a może nawet wzmocnienie jego dyscypliny ${ }^{20}$.

Po trzecie: Synod Biskupów egzaminuje kwestie dotyczące działalności Kościoła w świecie ${ }^{21}$.

Sukcesywnie nasz autor stwierdził w swojej konkluzji, że „pierwszym aspektem tego potrójnego oblicza Synodu jest relacja między Biskupem Rzymskim a Kolegium Biskupów. Mówiąc inaczej: Synod służy poprawnej relacji między jednością a katolickością Kościoła, to znaczy faworyzuje tę jedność, która będąc jego żywotną częścią, rozwija się w witalności Kościołów partykularnych. Drugi aspekt odpowiada pomocy świadczonej Biskupowi Rzymskiemu; trzeci działalności Kościoła w świecie. Stąd też relacja między Biskupem Rzymskim a Kolegium Biskupów, relacja Biskupa Rzymskiego z Kościołem powszechnym, relacja Kościoła ze światem: te trzy relacje tworzą jedną rzeczywistość, która nazywa się Synodem Biskupów. ... Innymi sło-

\footnotetext{
${ }^{18}$ „Synod Biskupów jest zebraniem biskupów, wybranych z różnych stron świata, którzy zbierają się w określonych terminach, ażeby pobudzać ścisłą łączność między Biskupem Rzymu i biskupami, jak również temuż Biskupowi Rzymskiemu świadczyć pomoc swoją radą w celu zachowania i wzrostu wiary oraz obyczajów, a także zachowania i umocnienia dyscypliny kościelnej, i rozważenia problemów związanych z działalnością Kościoła w świecie”, KPK, kan. 342.

${ }^{19}$ J. RATZINGER, dz. cyt., s. 46.

${ }^{20}$ Tamże.

${ }^{21}$ Tamże.
} 
wy: potrójny cel teologiczny wydaje się być włączonym w jedyną konfigurację prawną, to znaczy w świadczenie pomocy Biskupowi Rzymskiemu ze strony wybranych biskupów ze wszystkich stron świata"22. Synod Biskupów ma zatem efektywnie wspomagać Biskupa Rzymskiego - można powiedzieć zatem, że taką właśnie naturę instytucji podkreślił w swojej wypowiedzi kard. Ratzinger; warto także zwrócić uwagę, iż jednocześnie obok ukazania natury teologicznej instytucji, wskazał także na pastoralny wymiar Synodu Biskupów ${ }^{23}$.

Po tym syntetycznym przedstawieniu wybranych elementów dotyczących natury instytucji Synodu Biskupów według J. Ratzingera, warto zacytować niektóre jego opinie w perspektywie reformy tej instytucji, przy czym autor zastrzegł sobie, że są to jedynie jego osobiste spostrzeżenia. Pośród nich należałoby wymienić, między innymi to, że nasz autor bardzo trafnie oraz praktycznie zauważył, iż jak powszechnie wiadomo, w ciągu zaledwie kilku tygodni prac Synodu Biskupów, można jedynie zredagować pewne opinie oraz propozycje, nie można natomiast wypracować dokumentów o charakterze definitywnym. Ta uwaga pozwoliła kard. Ratzingerowi na stwierdzenie, że Synod Biskupów nie powinien posiadać głosu decydującego, co wyjaśnił właśnie względami o charakterze praktycznym ${ }^{24}$.

Stwierdził sukcesywnie, że „klimat” Synodu Biskupów w dużej mierze zależy od zastosowanej metody pracy. W tej perspektywie zauważył bardzo krytycznie, że uczestniczenie w serii wcześniej przygotowanych przemówień wygłaszanych przez biskupów w auli synodalnej, pozbawionych często oryginalnych zagadnień do dyskusji, charakteryzujących się ekspozycją zasadniczo ogólną i pozbawioną związku z analizowaną tematyką na zgromadzonym Synodzie Biskupów, skutkuje stanem zmęczenia czy też znużenia u samych ojców synodalnych, którzy w ten sposób nie tylko nie widzą żadnego postępu w poszukiwaniu prawdy ale spotykają się jedynie z powtarzanymi argumentami, co niewątpliwie nie ma nic wspólnego z kreatywnym

\footnotetext{
22 Tamże, s. 46n.

${ }^{23}$ Tamże, s. 48.

${ }^{24}$ Tamże, s. 49.
} 
charakterem instytucji. Z drugiej strony, sukcesywna druga część Synodu Biskupów, a więc ta, która winna posiadać charakter twórczy w perspektywie konkluzji finalnych, charakteryzuje się zbytnią szybkością, która wprowadza pytanie o rzeczywistą powagę prac synodalnych. W tej sytuacji J. Ratzinger stawia bardzo konkretne pytanie: co robić? ${ }^{25}$.

Odpowiadając - na tak postawione pytanie - stwierdził między innymi, że jest rzeczą konieczną, aby dyskusja na Synodzie Biskupów dotyczyła poszczególnych argumentów, aby był ponadto określony czas dotyczący wypowiedzi na ich temat, naturalnie z wyłączeniem tego, co nie dotyczy dyskutowanych kwestii; zasugerował wprost, aby poszczególne Konferencje Biskupów nie przygotowywały wcześniej swoich wypowiedzi (winny to zrobić poprzez włączenie się do przygotowywanego przed Synodem Biskupów „,instrumentum laboris”), ale by posyłały na Synody biskupów kompetentnych oraz dobrze przygotowanych, zdolnych do odpowiedzi na to, co jest dyskutowane oraz gotowych, wraz ze swoją odpowiedzialnością biskupią, włączyć się w dyskusję, która będzie dążyła do poznania prawdy ${ }^{26}$. Jak widać kard. Ratzinger był twórczo-krytyczny wobec istniejącej wówczas rzeczywistości Synodu Biskupów, w szczególności zaś względem postaw niektórych biskupów, przybyłych do Rzymu na jego zebranie.

Ponadto wskazał, że dyskutowane argumenty winny być tak zawężone, aby mogły zostać przedstawione Biskupowi Rzymskiemu w formie konkretnych propozycji, oraz aby mogły wyrazić generalną linię synodalnego myślenia, jednocześnie bez szukania perfekcyjnej formy wypowiedzi; wydaje się, iż na to będzie czas w posynodalnym dokumencie Biskupa Rzymskiego. Wskazał także, że istnieje potrzeba, aby na zgromadzonym Synodzie Biskupów, głos Kościoła powszechnego wyraził się poprzez jego siłę jedności na temat ważnych problemów naszych czasów. J. Ratzinger podkreślił także, że synodalny wysiłek wymaga zaangażowania wszystkich sił, oraz że ludzie współcześni nie

\footnotetext{
${ }^{25}$ Tamże, s. 55.

${ }^{26}$ Tamże, s. 55n.
} 
oczekują dyskusji ale przede wszystkim wspólnego wysiłku, do którego wezwał Pan Bóg ${ }^{27}$.

Przypomniane - choć skrótowo - wybrane myśli kard. Ratzingera na temat natury oraz funkcjonowania instytucji Synodu Biskupów, są niewątpliwie bardzo kompetentne oraz trafne; ponadto należałoby także podkreślić, że również i dzisiaj pozostają one aktualne i warto było do nich powrócić, szczególnie do tych o charakterze praktycznym, które chcą kształtować dynamikę analizowanej instytucji współczesnego Kościoła posoborowego.

\section{Synody Biskupów Benedykta XVI}

Zanim przejdziemy do przedstawienia Synodów Biskupów, które odbyły się za pontyfikatu Benedykta XVI, których było w sumie pięć, należy również przypomnieć, iż podczas tego pontyfikatu został także opublikowany nowy Regulamin Synodu Biskupów ${ }^{28}$.

Rescriptum ex Audientia z dnia 29 września 2006 r. informuje, że papież Benedykt XVI, po zapoznaniu się z opinią Sekretariatu Generalnego Synodu Biskupów na temat stosowności uaktualnienia wcześniejszego Regulaminu Synodu Biskupów z 1966 r. (przejrzanego i rozszerzonego w 1969 i 1971), w szczególności w celu dostosowania go do dyspozycji obowiązującego Kodeksu Prawa Kanonicznego oraz Kodeksu Kanonów Kościołów Wschodnich, zatwierdził oraz polecił opublikować nowy Regulamin instytucji ${ }^{29}$. Benedykt XVI zarządził także, aby nowy Regulamin Synodu Biskupów, był sumiennie zachowywany przez tych, do których się odnosi ${ }^{30}$. Regulamin Synodu Biskupów z 2006 r. posiada Wstęp oraz trzy części na temat najwyższego autorytetu oraz uczestników Synodu Biskupów (część pierwsza), normy generalne (druga część) oraz artykuły na temat obowiązującej procedury na Synodzie Biskupów (trzecia część); do powyższego

${ }^{27}$ Tamże, s. 58.

${ }^{28}$ Zob. T. Rozkrut, Zebranie Synodu Biskupów wedtug Regulaminu z 2006, Annales Canonici, 7(2011), s. 113-131.

${ }^{29}$ Ordo Synodi Episcoporum, w: AAS, 98 (2006), s. 755-779.

${ }^{30}$ Rescriptum ex Audientia, w: AAS, 98 (2006), s. 755. 
Regulaminu został dołączony Aneks na temat sposobu postępowania w „Circulis Minoribus”.

\subsection{Zebranie Generalne Zwyczajne Synodu Biskupów (2005)}

Papież Benedykt XVI po raz pierwszy przewodniczył Synodowi Biskupów w dniach 2 - 23 października 2005 r. Wprawdzie XI Zebranie Generalne Zwyczajne Synodu Biskupów - jak już to zostało wskazane wcześniej - zostało zapowiedziane przez papieża Jana Pawła II, ale obradom tego Synodu Biskupów, który zgromadził 256 ojców synodalnych wokół tematu: „Eucharystia: źródło oraz szczyt życia i misji Kościoła", przewodniczył już nowy Biskup Rzymski ${ }^{31}$. Synod Biskupów został poprzedzony opublikowaniem Lineamenta $\mathrm{w}$ dniu 25 lutego $2004 \mathrm{r}^{32}$, jak również sukcesywnie dnia 7 lipca 2005 r. zostało opublikowane Instrumentum laboris dla tego Synodu $^{33}$. XI Zebranie Generalne Synodu Biskupów opublikowało swoje zwyczajowe Przesłanie synodalne (Pace a voi) dnia 22 października 2005 r. $^{34}$, jak również 50 swoich propozycji ${ }^{35}$ oraz, także 22 października 2005 r., List do biskupów chińskich nieobecnych na zgromadzonym Synodzie Biskupów ${ }^{36}$. Dnia 22 lutego 2007 r. papież Benedykt XVI podpisał posynodalną adhortację apostolską ,Sacramentum caritatis" 37 .

${ }^{31}$ Segreteria Generale del Sinodo dei Vescovi (red.), Enchiridion del Sinodo dei Vescovi, 1996-2007, t. 3, Bologna 2008, s. 7265.

${ }^{32}$ Segreteria Generale del Sinodo dei Vescovi, Lineamenta XI Coetus generalia ordinarii, Città del Vaticano 2004.

${ }^{33}$ Segreteria Generale del Sinodo dei Vescovi (red.), Enchiridion del Sinodo dei Vescovi, t. 3, dz. cyt., s. 7265.

${ }^{34}$ Synodus EpISCOPORUm, Nuntius datus ab XI Coetu Generali Ordinario Synodi Episcoporum, w: AAS, 97(2005), s. 988-999.

${ }^{35}$ Elenco finale delle Proposizioni (22 ottobre 2005), w: Segreteria Generale del Sinodo dei Vescovi (red.), Enchiridion del Sinodo dei Vescovi, t. 3, dz. cyt., s. 74707497.

${ }^{36}$ Segreteria Generale del Sinodo dei Vescovi (red.), Enchiridion del Sinodo dei Vescovi, t. 3, dz. cyt., s. 7496-7499.

${ }^{37}$ Benedictus XVI, Adhortatio apostolica postsynodalis ,, Sacramentum caritatis”, w: AAS, 99(2007), s. 105-180. 
Podczas Mszy św. celebrowanej dnia 23 października 2005 r. na zakończenie tego Synodu Biskupów papież Benedykt XVI powiedział, między innymi, że wspólnota tego Synodu przez trzy tygodnie przeżywała klimat odnowionej żarliwości eucharystycznej i dodał, że pragnie wraz ze wszystkim ojcami synodalnymi oraz w imieniu całego Episkopatu, przesłać braterskie pozdrowienie biskupom w Chinach. Dodał także, że z prawdziwym żalem przyjął brak obecności ich przedstawicieli w Rzymie, dodając jednocześnie, że pragnie zapewnić biskupów chińskich, jak również kapłanów oraz wiernych świeckich o bliskości modlitewnej. Odnosząc się natomiast do prac zakończonego Synodu Biskupów, Benedykt XVI wskazał, że prace tego Synodu Biskupów - który miał miejsce w Roku Eucharystii - pozwoliły na pogłębienie znaczących aspektów tajemnicy tego sakramentu: ,kontemplacja Eucharystii powinna zachęcić wszystkich członków Kościoła, w pierwszym miejscu kapłanów, szafarzy Eucharystii, do odnowienia ich zobowiązania do wierności. Na tajemnicy eucharystycznej, celebrowanej oraz adorowanej, opiera się celibat, który kapłani otrzymują jako cenny dar oraz znak niepodzielnej miłości Boga oraz drugiego człowieka. Także dla wiernych świeckich duchowość eucharystyczna winna być wewnętrzną siłą każdej działalności i żadna dychotomia nie jest dopuszczalna między wiarą a ich życiem w chrześcijańskiej misji animacji świata" 38 .

\subsection{Zebranie Generalne Zwyczajne Synodu Biskupów (2008)}

XII Zebranie Generalne Zwyczajne Synodu Biskupów, w którym uczestniczyło 253 ojców synodalnych, odbyło się w dniach 5-26 październik 2008 r. Problematyka tego zgromadzenia Synodu Biskupów dotyczyła roli Słowa Bożego w życiu oraz misji Kościoła. Prace tego Synodu Biskupów zostały poprzedzone wydaniem dnia 27 kwietnia 2007 r. przedsynodalnych Lineamenta pt. „Słowo Boże w życiu oraz misji Kościoła”; sukcesywnie pod takim samym tytułem zostało opu-

${ }^{38}$ Omelia del Santo Padre Benedetto XVI, w: R. Nardin (red.), L'Eucaristia: fonte e culmine della vita e della missione della Chiesa, Lateran University Press, Roma 2008, s. 625 . 
blikowane Instrumentum laboris dnia 11 czerwca 2008 r. ${ }^{39}$. Synod Biskupów dnia 24 października 2008 r. opublikował swoje Przesłanie do Ludu Bożego, jak również swoje końcowe propozycje ${ }^{40}$. Sukcesywnie papież Benedykt XVI opublikował dnia 30 września 2010 r. posynodalną adhortację apostolską pt. „Dei Verbum”.

Wracając natomiast do samego przebiegu Synodu Biskupów na temat Bożego Słowa, to należałoby podkreślić, że przemawiając podczas Mszy św. na otwarcie Synodu Biskupów dnia 5 października 2008 r. papież Benedykt XVI - w Roku św. Pawła - powiedział, że także i dzisiaj Kościół nieustannie proklamuje Dobrą Nowinę, biorąc przykład z Apostoła Narodów, który ją głosił w różnych rejonach Azji Mniejszej oraz Europy; „odnowimy w sposób specyficzny to głoszenie podczas XII Zgromadzenia Generalnego Zwyczajnego Synodu Biskupów, który ma jako temat: Słowo Boże w życiu i misji Kościoła. [...] Jedynie Słowo Boże może zmieniać głębokości serca ludzkiego, stąd też jest ważne, aby w tę coraz bardziej rosnącą wewnętrzną relację z nim, wchodzili poszczególni wierzący oraz wspólnoty. Zgromadzenie synodalne zwróci swoją uwagę na tę prawdę fundamentalną dla życia oraz misji Kościoła"41.

Z kolei podczas Mszy św. kończącej Synod Biskup na temat Słowa Bożego papież Benedykt XVI dnia 26 października 2008 r. powiedział, że podczas zakończonych prac synodalnych tyle razy „słyszeliśmy doświadczenia oraz refleksje, które zwracają szczególną uwagę na dzisiejszą wyłaniającą się potrzebę bardziej intymnego słuchania Boga, jeszcze lepszego poznawania jego słowa zbawienia; bardziej szczerego dzielenia się wiarą, która przy stole Bożego Słowa stale się pożywia"42. W konkluzji swojej homilii Benedykt XVI zapowiedział II Zebranie Specjalne Synodu Biskupów dla Afryki, który odbędzie się w Rzymie w październiku 2009 r., zapowiedział także, że jest jego

\footnotetext{
${ }^{39}$ L'Osservatore Romano, 13 giugno 2008, s. 1.

${ }^{40}$ L'Osservatore Romano, 25 ottobre 2008, s. 1.

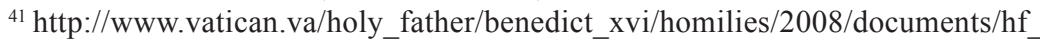
ben-xvi_hom_20081005_apertura-sinodo_it.html (28.08.2013).

${ }^{42} \mathrm{http}$ ://www.vatican.va/holy_father/benedict_xvi/homilies/2008/documents/hf ben-xvi_hom_20081026_conclusione-sinodo_it.html (28.08.2013).
} 
zamiarem udać się do Kamerunu w marcu 2009 r., aby osobiście przekazać reprezentantom poszczególnych Konferencji Biskupów Afryki Instrumentum laboris przygotowywanego synodu afrykańskiego ${ }^{43}$.

2.3. II Zebranie Specjalne Synodu Biskupów dla Afryki (2009)

W dniach 4 - 25 października 2009 r. odbyło się II Zebranie Specjalne Synodu Biskupów dla Afryki. Uczestniczyło w nim 244 ojców synodalnych a tematem tego kontynentalnego Synodu Biskupów były słowa: „Kościół w Afryce w służbie pojednania, sprawiedliwości i pokoju. «Wy jesteście solą ziemi (...). Wy jesteście światłem świata (Mt 5, 13-14)»" "44. Dnia 27 czerwca 2006 r. zostały opublikowane $\mathrm{Li}$ neamenta do tego Synodu Biskupów, natomiast Instrumentum laboris zostało opublikowana dnia 19 marca 2009 r., podczas wizyty apostolskiej papieża Benedykta XVI w Afryce ${ }^{45}$. Tenże Synod Biskupów dnia 23 października 2009 r. opublikował swoje Przesłanie do Ludu Bożego, także w tym samym dniu zostały zatwierdzone końcowe Propozycje II Zebrania Specjalnego Synodu Biskupów dla Afryki ${ }^{46}$. Dnia 19 listopada 2011 r. została natomiast opublikowana posynodalna adhortacja apostolska papieża Benedykta XVI pt. „Africae munus” na temat Kościoła w Afryce w służbie pojednaniu, sprawiedliwości i pokoju.

Rozpoczynając to specjalne zgromadzenie Synodu Biskupów papież Benedykt XVI powiedział podczas Mszy św. dnia 4 października 2009 r., że właśnie mija piętnaście lat jak 10 kwietnia 1994 r. Sługa Boży Jan Paweł II otworzył pierwsze Zebranie Specjalne Synodu Biskupów dla Afryki. I Zebranie Specjalne Synodu Biskupów dla Afryki (10 kwietnia - 8 maja 1994) na temat Kościół w Afryce oraz jego misja ewangelizacyjna $w$ obliczu roku 2000: „Będziecie moimi świadkami (Dz 1,8)", zgromadził 242 ojców synodalnych ${ }^{47}$. Papież Jan Paweł II

${ }^{43}$ Tamże.

${ }^{44}$ II Specjalne Zgromadzenie Synodu Biskupów poświęcone Afryce, Kronika Synodu, L'Osservatore Romano, wydanie polskie, 1 (2010) 25.

${ }^{45}$ L'Osservatore Romano, 20-21 marzo 2009, s. 1.

${ }^{46}$ L'Osservatore Romano, 24 ottobre 2009, s. 1.

${ }^{47}$ Segreteria Generale del Sinodo dei Vescovi (red.), Enchiridion del Sinodo dei Vescovi, t. 2, Bologna 2006, s. 3529. 
wydał także posynodalną adhortację apostolską „Ecclesia in Africa” (14 września 1995) ${ }^{48}$, która została przez niego podpisana podczas wizyty apostolskiej w Afryce w dniach od 14 do 20 września 1995 r. ${ }^{49}$.

\subsection{Synod Biskupów dla Bliskiego Wschodu (2010)}

Synod Biskupów poświęcony Kościołowi na Bliskim Wschodzie odbył się z Rzymie w dniach od 10 do 24 października 2010 r. a uczestniczyło w nim 185 ojców synodalnych. Prace tego Synodu zostały poprzedzone opublikowaniem, pod takim samym tytułem: «Kościół katolicki na Bliskim Wschodzie: Wspólnota i świadectwo: ,Jeden duch i jedno ciało ożywiały wszystkich wierzących” (Dz 4, 32)», przez Sekretariat Generalny Synodu Biskupów dwóch dokumentów w perspektywie tego Synodu Biskupów. Najpierw dnia 8 grudnia 2009 r. zostały opublikowane Lineamenta, oraz sukcesywnie dnia 6 czerwca 2010 r. zostało opublikowane Instrumentum laboris. Ten Synod Biskupów zakończył się opublikowaniem Przesłania do Ludu Bożego dnia 22 października 2010 r. oraz jego zwyczajowych już Propozycji finalnych dnia 26 października 2010 r. Sukcesywnie podczas swojej wizyty apostolskiej w Libanie papież Benedykt XVI podpisał dnia 14 września 2012 r. posynodalną adhortację apostolską „Ecclesia in Medio Oriente". W tym miejscu wypada także przypomnieć, że w dniach 26 listopada - 14 grudnia 1995 r. odbył się Specjalny Synod Biskupów dla Libanu, w którym wzięło udział 69 ojców synodalnych. Rozważali oni temat: Chrystus jest naszą nadzieją: odnowieni przez jego Ducha, solidarnie dajemy świadectwo jego miłości ${ }^{50}$. Sukcesywnie, podczas swojej wizyty apostolskiej w Libanie, dnia 10 maja 1997 r. w Bejrucie, papież Jan Paweł II podpisał posynodalną adhortację apostolską „Une espérance nouvelle"51,

\footnotetext{
${ }^{48}$ Ioannes Paulus II, Adhortatio apostolica postsynodalis „Ecclesia in Africa”, w: AAS, 88(1996), s. 5-82.

${ }^{49}$ Segreteria Generale del Sinodo dei Vescovi (red.), Enchiridion del Sinodo dei Vescovi, t. 2, dz. cyt., s. 3529.

${ }^{50}$ Segreteria Generale del Sinodo dei Vescovi (red.), Enchiridion del Sinodo dei Vescovi, t. 2, dz. cyt., s. 4573.

${ }^{51}$ Ioannes Paulus II, Adhortatio apostolica post Synodum pro Libano „, Une espérance nouvelle pour le Liban”, w: AAS, 89(1997), s. 313-416.
} 
która została przetłumaczona w 1998 r. przez patriarchów oraz biskupów Libanu na język arabski ${ }^{52}$.

Podczas Mszy św. na rozpoczęcie Synodu Biskupów dla Bliskiego Wschodu dnia 10 października 2010 r. papież Benedykt XVI, między innymi, powiedział, że na Bliskim Wschodzie ,jedyny Kościół Chrystusa wyraża się w różnorodności Tradycji liturgicznych, duchowych, kulturalnych oraz dyscyplinarnych sześciu czcigodnych Katolickich Kościołów Wschodnich sui iuris, jak również w Tradycji łacińskiej. [...] przyjąłem chętnie propozycję Patriarchów oraz Biskupów, aby zwołać zebranie synodalne w celu podjęcia wspólnej refleksji, w świetle Pisma Świętego oraz Tradycji Kościoła, na temat teraźniejszości oraz przyszłości wiernych oraz populacji Bliskiego Wschodu. [...] Stąd też cel tego zgromadzenia ma przeważający charakter duszpasterski" "53.

Z kolei podsumowując powyższy Synod Biskupów, podczas Mszy św. celebrowanej dnia 24 października 2010 r., papież Benedykt XVI podkreślił, że podczas prac tego zgromadzenia Synodu Biskupów wskazywano często na konieczność ponownego zaproponowania Ewangelii osobom, które mało ją znają, czy też po prostu oddaliły się od Kościoła. Także często podnoszono potrzebę nowej ewangelizacji także na Bliskim Wschodzie, przy czym Benedykt XVI w konkluzji swojej homilii powiedział, że zdecydował, aby najbliższy Synod Biskupów, który odbędzie się w 2012 r., podjął temat nowej ewangelizacji - „Nova evangelizatio ad christianam fidem tradendam” ${ }^{54}$.

2.5. XIII Zebranie Generalne Zwyczajne Synodu Biskupów (2012)

XIII Zebranie Generalne Zwyczajne Synodu Biskupów odbyło się w Rzymie w dniach od 7 do 28 października 2012 r., w tym także czasie został otwarty zainicjowany przez papieża Benedykta XVI Rok Wiary. W Synodzie tym uczestniczyło 262 ojców synodalnych.

${ }^{52}$ Segreteria Generale del Sinodo dei Vescovi (red.), Enchiridion del Sinodo dei Vescovi, t. 2, dz. cyt., s. 4573.

${ }^{53} \mathrm{http}: / /$ www.vatican.va/holy_father/benedict_xvi/homilies/2010/documents/hf ben-xvi_hom_20101010_sinodo-mo_it.html (28.08.2013).

${ }^{54} \mathrm{http}$ //www.vatican.va/holy_father/benedict_xvi/homilies/2008/documents/hf_ ben-xvi_hom_20101024_chiusura-sinodo-mo_it.html (28.08.2013). 
W perspektywie tego zgromadzenia synodalnego zostały przygotowane oraz opublikowane dnia 4 marca 2011 r. Lineamenta zatytułowane „Nowa ewangelizacja dla przekazu wiary chrześcijańskiej”, sukcesywnie dnia 19 czerwca 2012 r. zostało opublikowane pod takim samym tytułem Instrumentum laboris.

XIII Zebranie Generalne Zwyczajne Synodu Biskupów skierowało, zresztą zgodnie ze swoim zwyczajem, przesłanie do Ludu Bożego ${ }^{55}$, natomiast zgodnie z art. 15 oraz 39 Regulaminu Synodu Biskupów (Ordo Synodi Episcoporum) zostały przedstawione papieżowi Benedyktowi XVI Propozycje synodalne ${ }^{56}$.

Mówiąc na temat zwołanego zgromadzenia synodalnego, papież Benedykt XVI podczas Mszy św. inaugurującej jego pracę, wskazał dnia 7 października 2012 r., że celem zgromadzenia synodalnego nie pozostaje jedynie zwykłe „dyskutowanie” - bowiem mamy tutaj do czynienia z instytucją Kościoła, której towarzyszy modlitwa oraz refleksja duchowa. Sukcesywnie, papież dodał, że problematyka ta odpowiada aktualnemu programowi duszpasterskiego życia Kościoła, który zostanie ubogacony Rokiem Wiary, a który uroczyście rozpocznie się dnia 11 października 2012 r. w pięćdziesiątą rocznicę otwarcia Soboru Watykańskiego II. Nowa ewangelizacja - wskazał dalej Benedykt XVI - dotyczy zasadniczo tych osób, które są wprawdzie ochrzczone, jednakże oddaliły się od Kościoła i postępują bez odnoszenia się do praktyk chrześcijańskich - ,zgromadzenie synodalne, które zostaje dzisiaj otwarte jest poświęcone tej właśnie nowej ewangelizacji, aby dopomóc tym osobom na nowo spotkać Chrystusa, który jedynie jest w stanie wypełnić głębokim sensem oraz pokojem naszą egzystencję w celu odkrycia wiary, źródła Łaski, która przynosi radość i nadzieję w życiu osobistym, rodzinnym oraz społecznym" ${ }^{57}$. Odnosząc się do przeczytanej ewangelii (Mk 10, 7-8) na temat nierozerwalności mał-

\footnotetext{
${ }^{55} \mathrm{http}: / / w w w . v a t i c a n . v a /$ roman_curia/synod/documents/rc_synod_doc_20121026_ message-synod_it.html (13.12.2012).

${ }^{56} \mathrm{http}: / /$ www.vatican.va/news_services/press/sinodo/documents/bollettino_25 xiii-ordinaria-2012/01_italiano/b33_01.html (13.12.2012).

${ }^{57} \mathrm{http}: / /$ www.vatican.va/holy_father/benedict_xvi/homilies/2012/documents/hf ben-xvi_hom_20121007_apertura-sinodo_it.html (13.12.2012).
} 
żeństwa, papież Benedykt XVI wskazał, że dzisiaj małżeństwo, stanowi samo w sobie Dobrą Nowinę dla współczesnego świata, w szczególności dla świata pozbawionego wartości chrześcijańskich, stąd też Kościół potwierdza oraz świadczy, że małżeństwo pozostaje nie tylko przedmiotem ale także podmiotem nowej ewangelizacji ${ }^{58}$.

Przemawiając natomiast w auli synodalnej 27 października 2012 r., Benedykt XVI zaznaczył, że w kontekście refleksji Synodu Biskupów, pragnie poinformować, że zdecydował, aby przekazać kompetencje nad seminariami duchownymi z Kongregacji ds. Edukacji Katolickiej, Kongregacji dla Duchowieństwa, natomiast kompetencje dotyczące Katechezy, z Kongregacji ds. Duchowieństwa, Papieskiej Radzie dla Promocji Nowej Ewangelizacji, co - jak zaznaczył - zostanie zawarte w stosownych dokumentach, które będą miały formę Listu apostolskiego Motu Proprio.

Odnosząc się natomiast do kończącego się zgromadzenia Synodu Biskupów, papież Benedykt XVI wskazał, że był on dla niego samego wydarzeniem rzeczywiście budującym, umacniającym oraz zachęcającym, przede wszystkim, przez fakt, że mógł na tym synodzie zobaczyć jak w zwierciadle Kościół powszechny wraz ze swoimi cierpieniami, zagrożeniami, niebezpieczeństwami oraz radościami i doświadczeniami obecności Chrystusa, także poprzez sytuacje trudne - ,słyszeliśmy jak Kościół także i dzisiaj rośnie, żyje. Myślę, np. o tym co zostało powiedziane na temat Kambodży, gdzie na nowo rodzi się Kościół, wiara; ale także o Norwegii, i tylu innych. Widzimy jak także i dzisiaj, również tam, gdzie tego nie oczekiwano, Chrystus jest obecny i mocny oraz jak działa także poprzez naszą pracę oraz naszą refleksję. Mimo, że Kościół czuje dzisiaj wiatry przeciwne, jednakże czuje przede wszystkim powiew Ducha Świętego, który nas wspomaga, pokazuje nam słuszną drogę; w ten sposób, wraz z nowym entuzjazmem, wydaje mi się, jesteśmy w drodze i dziękujemy Panu, że dał nam to spotkanie rzeczywiście katolickie" ${ }^{59}$. Komentując te słowa należałoby zauważyć,

${ }^{58}$ Tamże.

${ }^{59} \mathrm{http}: / / w w w . v a t i c a n . v a / h o l y \_f a t h e r / b e n e d i c t \_x v i / s p e e c h e s / 2012 /$ october/documents/hf_ben-xvi_spe_20121027_sinodo_it.html (13.12.2012). 
że w ten sposób papież Benedykt XVI wskazał jak na Synodzie Biskupów jest, przede wszystkim, przeżywane doświadczenie Kościoła powszechnego oraz jak są uświadamiane jego problemy, a także jakie są wskazywane możliwości ich rozwiązania.

Odnosząc się natomiast do przedstawionych Propozycji (Propositiones), które można określić jako wewnętrzny owoc zgromadzenia synodalnego przygotowany właśnie jako jego głos doradczy dla Biskupa Rzymskiego, Benedykt XVI powiedział, że są one testamentem, darem, informacjami, które otrzymał w celu przepracowania tego wszystkiego w dokument, który będzie pochodził od życia oraz, który powinien rodzić życie ${ }^{60}$. W ten sposób, przynajmniej formalnie, została otwarta droga dla powstania nowej posynodalnej adhortacji apostolskiej.

Z kolei w homilii podczas Mszy św. na zakończenie Synodu Biskupów, papież Benedykt XVI dnia 28 października 2012 r., powiedział, że nowa ewangelizacja dotyczy całego Kościoła - „odnosi się ona, w pierwszym miejscu, do zwyczajnego duszpasterstwa, które musi być ożywiane przez ogień Ducha Świętego, aby rozpalić serca wiernych, którzy regularnie uczestniczą w życiu Wspólnoty i którzy gromadzą się w Dzień Pański, aby posilać się Słowem oraz Chlebem życia wiecznego" "61. Sukcesywnie papież dodał, że chciałby podkreślić trzy linie pastoralne, które ukazał Synod.

Pierwsza z nich dotyczy Sakramentów inicjacji chrześcijańskiej. Została na zgromadzeniu synodalnym potwierdzona konieczność towarzyszenia poprzez właściwą katechezę należytemu przygotowaniu do Chrztu, Bierzmowania oraz Eucharystii, ponadto podkreślono znaczenie Pokuty, jako sakramentu Bożego miłosierdzia - ,poprzez to itinerario sakramentalne przychodzi wołanie Pana do świętości, skierowane do wszystkich chrześcijan"62.

Na drugim miejscu należy wskazać, że nowa ewangelizacja jest istotnie związana z misją ad gentes. Kościół ma obowiązek ewange-

\footnotetext{
${ }^{60}$ Tamże.

${ }^{61} \mathrm{http}: / /$ www.vatican.va/holy_father/benedict_xvi/homilies/2012/documents/hf ben-xvi_hom_20121028_conclusione-sinodo_it.html (13.12.2012).

${ }^{62}$ Tamże.
} 
lizowania, przekazywania orędzia zbawienia wszystkim ludziom, którzy jeszcze nie znają Chrystusa - „także w czasie refleksji synodalnej zostało podkreślone, że istnieją jeszcze liczne środowiska w Afryce, Azji oraz Oceanii, których mieszkańcy oczekują z żywym zainteresowaniem, często nie posiadając pełnej tego świadomości, pierwszego głoszenia Ewangelii ... Globalizacja spowodowała znaczne przemieszczenie populacyjne; stąd też to głoszenie należy mieć także na uwadze w relacji do krajów dawno już ewangelizowanych. Wszyscy ludzie mają prawo, aby poznać Jezusa Chrystusa oraz jego Ewangelię; temu odpowiada obowiązek chrześcijan, wszystkich chrześcijan - kapłanów, zakonników i świeckich - głoszenia Dobrej Nowiny" ${ }^{63}$.

Trzeci aspekt dotyczy osób ochrzczonych, które jednak nie żyją wymogami Chrztu - „w czasie prac synodalnych zostało naświetlone, że takie osoby znajdują się na wszystkich kontynentach, szczególnie w krajach bardziej zeświedczonych ... Oprócz tradycyjnych metod duszpasterskich, zawsze ważnych, Kościół poszukuje także nowych metod, troszcząc się o nowy język, dostosowany do różnych kultur świata, przedstawiając prawdę Chrystusa poprzez dialog oraz przyjaźń, które mają swój fundament w Bogu, który jest Miłością" ${ }^{64}$.

\section{Podsumowanie}

Przypomniane, niewątpliwie ważne wydarzenia eklezjalne z zakończonego pontyfikatu papieża Benedykta XVI, pozostają nie tylko ważnym znakiem żywotności współczesnego Kościoła, ale trzeba je także widzieć w nurcie ich znaczenia dla reformy dzisiejszego Kościoła, zapoczątkowanej przez nowego papieża Franciszka. Mogą one służyć także celem jej wzmocnienia, przede wszystkim, w aspekcie doktrynalno-dyscyplinarnym; niewątpliwie uświadamiają ważne problemy współczesnego Kościoła oraz stojące przed nim wyzwania.

Pontyfikat papieża Benedykta XVI przeszedł do historii. Należałoby jednak zapytać jak ,jego” Synody Biskupów zostały przeszczepione, czy też przeniesione, do życia współczesnego Kościoła, przede

\footnotetext{
${ }^{63}$ Tamże.

${ }^{64}$ Tamże.
} 
wszystkim jak wygląda ich urzeczywistnianie w życiu Kościołów partykularnych? Czy nie są to tylko instytucje, które przeszły do historii i zupełnie została pominięta ich dynamika, przede wszystkim, poprzez ukazanie nowych przestrzeni działania. Na to pytanie powinni odpowiedzieć, przede wszystkim, biskupi. Wydaje się, że pytanie to należy stawiać szczególnie w odniesieniu do ostatniego Synodu Biskupów zwołanego przez Benedykta XVI na temat nowej ewangelizacji i odbytego w Roku Wiary.

Konkludując należałoby także zauważyć, że Synody Biskupów odbyte podczas pontyfikatu papieża Benedykta XVI, to niewątpliwie także odzwierciedlenie tego pontyfikatu; w szczególności pomogły one Biskupowi Rzymskiemu spojrzeć w świetle powszechności Kościoła na ważne aktualne problemy, jak również wypracować nowe kierunki działań duszpasterskich.

\section{Synods of Bishops of the Pope Benedict XVI}

An important institution of the post-conciliar Church, and - as we can even say - a sign of his life and dynamism, and first of all, concern of common good, is relatively young and lively institution of the Synod of Bishops. It was called into existence during the period of the Second Vatican Council by the Pope Paul VI (1963-1978), largely as a response to the suggestions in the perspective of aggiornamento. The institution of the Synod of Bishops became particularly lively during a long pontificate of the Pope John Paul II (1978-2005) who chaired its 15 meetings and announced the Synod of Bishops concerning the Eucharist that took place during the pontificate of the Pole Benedict XVI. Also, the Pope Benedict XVI (2005-2013) regularly called the Synod of Bishops maintaining a creative influence of the Bishop of Rome on functioning of the contemporary universal Church this way. Synods of Bishops that took place during the pontificate of the Pope Benedict XVI are undoubtedly the reflection of this pontificate; in particular they helped the Bishop of Rome to take a look, in the light of the universality of the Church, at the current significant problems as well as develop new directions of pastoral actions. 